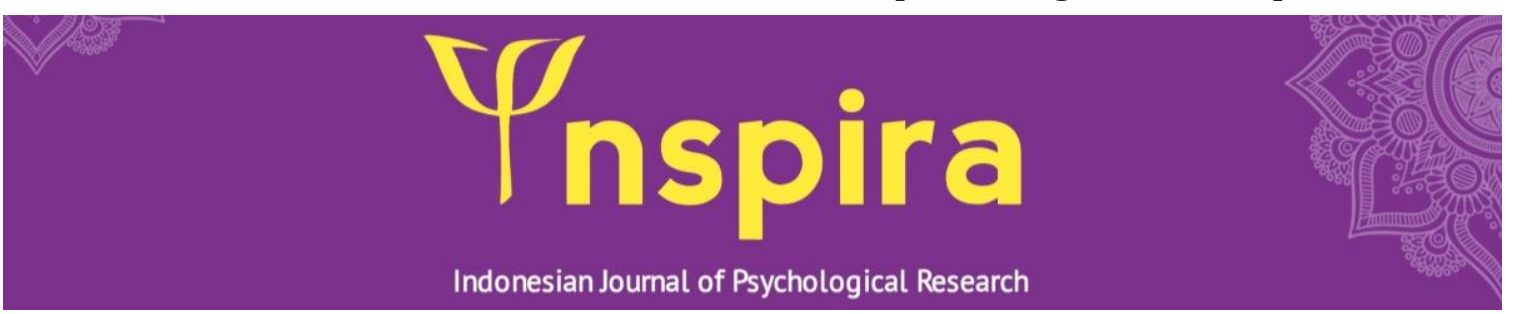

\title{
Self-regulation as a predictor of Fear of Missing Out in emerging adulthood
}

Dedy Surya ${ }^{1 凶}$, Dara Aulina ${ }^{2}$

${ }^{1}$ Department of Islamic Guidance and Counseling, Institut Agama Islam Negeri Langsa, Aceh, Indonesia; ${ }^{2}$ Department of Psychology, Universitas Malikussaleh, Aceh, Indonesia.

Corresponding author:

Dedy Surya (email: dedysurya@iainlangsa.ac.id)

\begin{abstract}
The use of social media due to the development of technology has implications for the tendency to know the activity in their social circle. This tendency is called Fear of Missing Out (FoMO). This study aims to determine the relationship between self-regulation and FoMO in emerging adulthood. By using quantitative correlational research methods, this study involved 99 students of the Department of Psychology, Malikussaleh University, Aceh, Indonesia with an emerging adulthood age range. The data in this study was collected using two scales, namely Self-Regulation Scale and FoMO Scale. Data analysis using Pearson Correlation. The results showed that there was no significant association between self-regulation variables and FoMO, indicated by the coefficient $\mathrm{r}=0.544$ and $\mathrm{p}=0.000<0.05$. This result means that there is a negative relationship between self-regulation and FoMO. Selfregulation contributed to FoMO in 4,00\%. There were still $96 \%$ other factors related to FoMO tendency. This research showed that selfregulation is too weak to predict FoMO in emerging adulthood.
\end{abstract}

\section{Article History:}

Received: January 5, 2020

Revised: February 1, 2020

Accepted: March 3, 2020

Published: June 18, 2020

\section{Keyword:}

emerging adulthood; Fear of Missing Out; freshmen; self-regulation

How to cite (APA $7^{\text {th }}$ Edition)

Surya, D., \& Aulina, D. (2020). Self-regulation as a predictor of Fear of Missing Out in emerging adulthood. INSPIRA: Indonesian Journal of Psychological Research, 1(1), 1-5. https://doi.org/10.32505/inspira.v1i1.1713 


\section{INTRODUCTION}

Advances in technology and information are now evolving. Technology and information can make it easier for anyone to get the information they need from anywhere and anytime through the digital world. Technology also allows people to be able to interact remotely and communicate with others in their daily life (Alutaybi et al., 2019).

The ease of obtaining various information is the main reason someone uses the internet. The development of this technology stimulates the increased desire to socialize through the internet (Jood, 2017). In addition, social media also grabs the attention of internet users because it allows its users to share photos, videos, and even stories with others online.

Data survey conducted by the Center for Communication Studies in collaboration with Asosiasi Penyelenggara Jasa Internet Indonesia (APJII) or Association of Indonesian Internet Service Providers stated that the highest number of internet users in Indonesia ranging in age from 18-25 years. The 18-25-year-old is a transition period from the late adolescence stage to early adulthood called emerging adulthood, especially adolescence. One of the characteristics of this phase is instability in various aspects of life, so many teenagers experience instability in their lives. The development of this technology does not cause problems. Its use is now growing into a new problem (Dempsey et al., 2019). Problems arising from internet users tend to create social difficulties — such as in school and/or work — as well as psychological difficulties (Alt \& BonielNissim, 2018; Beard \&Wolf, 2001). One of the trends that the internet is causing is Fear of Missing Out (FoMO).

FoMO is a feeling of discomfort or loss as a result of knowing what others are doing and feeling that it is more enjoyable, more valuable than it is (Abel et al., 2016). FoMO is characterized by a desire to always want to know the activities of others posted on social media, and the tendency to always compare the lives of others to their lives (Przybylski et al., 2013). FoMO causes one to utilize digital technology to stay online to stay connected to the social activities of those around them (Hadlington \& Scase, 2018).

FoMO can also result in someone trying to be the same as what someone else posts, whether it's in terms of activity, material, or experience. FoMO is also common in adolescents, especially in students, students who experience high FoMO, will affect their lives, one of which is decreased productivity, decreased academic achievement, low learning motivation, and it makes the learning process disrupted. Furthermore, a study conducted by Jood (2017) showed that FoMO causes a person to tend to have low life satisfaction.

Huang (2014) stated that the cause of a person experiencing social media addiction is because they are unable to manage and manage their time, causing boredom and choosing to spend time accessing social media.

This study aims to investigate the extent to which self-regulation can be a predictor of FoMO tendencies in adolescents growing up. Self-regulation is described as a form of an individual's ability to manage his actions on his goals and dreams in the future. Furthermore, someone who has good self-regulation will be able to adjust to the demands of society and its environment (Matric, 2018). Self-regulation can control itself with its cognition and behavior so that the individual can control the anxiety affected by external stimulus. 


\section{RESEARCH METHOD}

This research was conducted on students of the Department of Psychology, Malikussaleh University Psychology, Aceh, Indonesia as a representation of emerging adulthood in the age range of 18-25 years. The sampling technique used in this study was a total side technique by taking the entire population to be sampled as many as 99 people. The research data was collected using the constructed Self-Regulation Scale of Bandura theory and FoMO scale from Przybylski, et al. (2013). The method of data analysis used in this study is to use the computer program SPSS (Statistical Package for Service Solutions) Version 22 using normality tests and correlation tests.

\section{RESULT}

The normality test on the data distribution was analyzed using a one-sample KolmogorovSmirnov test. Based on the results of the normality test, it is known that the value is significant (Asymp. Sig. (2-tailed)) for self-regulation of 0.038 and FoMO of 0.013 , so the significance of both variables is greater than 0.05 . Thus, it can be concluded that the distribution of data on both variables is normally distributed.

Pearson's correlation test aims to measure the relationship between two variables linearly and to determine the direction of the relationship occurring (Priyanto, 2011). The r-count value for the relationship between self-regulation and FoMO is $0.544(>0.062)$ accompanied by a significant value (p) of $0.000<0.05$ which means there is a significant relationship between selfregulation variables and FoMO variables. This means the degree of connection is no correlation.

\section{DISCUSSION}

Based on the results of data testing that has been conducted by researchers, the following will be presented the results of research obtained from two variables, namely self-regulation and FoMO. The results showed that there is a significant association between self-regulation and FoMO tendencies that arise in adolescent behavior in adulthood. However, self-regulation has a very small contribution to FoMO tendencies.

Thus, it can be decided that self-regulation is not able to predict the tendency of FoMO behavior that arises. That is, the high or low self-regulation of an individual has very little to do with the level of FoMO.

Results of previous research conducted by Wanjohi, et. al. (2015) explained that students who have high self-regulation can control the use of social media and will avoid negative effects such as attraction to social media to compulsive and addictive use. This study is inversely proportional to research conducted by Arnet (2013) which explains that the use of social media in times of emerging adulthood tends to use the internet excessively.

The findings of this study are supported by the results of research conducted by Sianipar \&Kaloeti (2019). This study mentions that self-regulation has a negative relationship with FoMO in first-year students but with a very small self-regulation contribution $(2.9 \%)$ contribute to the tendency of FoMO in students so it is difficult to mention predicting FoMO tendencies that arise through the level of self-regulation owned by individuals.

In this study, psychology new students have high self-regulation, so the regulation owned by new students of psychology indicates that they can control the use of technology tends to be 
good, including how to utilize technology as a learning tool and socializing tools with the technology environment. Time transparency on social media today is one of the triggering factors for FoMO so that individuals can easily see and compare their experiences, especially through social media.

\section{CONCLUSION}

From the discussion above, it can be concluded that regulation of having a relationship with the tendency of FoMO in emerging adulthood. Although with very small predictability, this shows that with efforts to increase the level of self-regulation, the tendency of adolescents to experience FoMO is decreasing. With the limitations of this study, there are some suggestions that researchers submit for further investigation, such as expanding research samples of various cultural backgrounds to see the influence of culture on FoMO tendencies. Then, it can also be by adding various other predictors, either in the form of free variables or mediator variables so that the study of FoMO is increasingly comprehensive. The current research used a quantitative method, so it has limitations in extracting and conveying data. Therefore, it is worth considering to research this with a qualitative approach (either through observation, interview, or FGD) that can test causality relationships more adequately and find models capable of explaining FoMO tendencies integrally.

\section{REFERENCES}

Abel, J. P., Buff, C. L., \& Burr, S. A. (2016). Social media and the fear of missing out: Scale development and assessment. Journal of Business \& Economics Research (JBER), 14(1), 33-44. https://doi.org/10.19030/jber.v14i1.9554

Alt, D., \& Boniel-Nissim, M. (2018). Links between adolescents' deep and surface learning approaches, problematic internet use, and Fear of Missing Out (FoMO). Internet Interventions, 13(June), 30-39. https://doi.org/10.1016/j.invent.2018.05.002

Alutaybi, A., Arden-Close, E., McAlaney, J., Stefanidis, A., Phalp, K., \& Ali, R. (2019). How can social networks design trigger fear of missing out? Conference Proceedings - IEEE International Conference on Systems, Man and Cybernetics, 2019-Octob, 3758-3765. https://doi.org/10.1109/SMC.2019.8914672

Arnet, J. J. (2013). Adolescence and emerging adulthood: A cultural approach (5th ed.). Pearson Education.

Beard, K. W., \& Wolf, E. M. (2001). Modification in the Proposed Diagnostic Criteria for internet addiction. CyberPsychology \& Bebavior, 4(3), 377-383. https://doi.org/10.1089/109493101300210286

Dempsey, A. E., O’Brien, K. D., Tiamiyu, M. F., \& Elhai, J. D. (2019). Fear of missing out (FoMO) and rumination mediate relations between social anxiety and problematic Facebook use. Addictive Behaviors Reports, 9(November 2018), 100150. https://doi.org/10.1016/j.abrep.2018.100150

Hadlington, L., \& Scase, M. O. (2018). End-user frustrations and failures in digital technology: exploring the role of fear of missing out, internet addiction and personality. Heliyon, 4(11), e00872. https://doi.org/10.1016/j.heliyon.2018.e00872

Huang, H. (2014). Social Media Generation in urban China (E. Yang \& N. P. Thomas (eds.)). Springer 
Berlin Heidelberg. https://doi.org/10.1007/978-3-642-45441-7

Jood, T. E. (2017). Missing the present for the unknown: The relationship between Fear of Missing Out (FoMO) and life satisfaction. University of South Africa.

Matric, M. (2018). Self-regulatory systems: Self-regulation and learning. Journal of Process Management. New Technologies, 6(4), 79-84. https://doi.org/10.5937/jouproman6-19338

Priyanto, D. (2011). Buku saku SPSS: Analisis statistik data. PT Buku Seru.

Przybylski, A. K., Murayama, K., Dehaan, C. R., \& Gladwell, V. (2013). Motivational, emotional, and behavioral correlates of fear of missing out. Computers in Human Behavior, 29(4), 18411848. https://doi.org/10.1016/j.chb.2013.02.014

Sianipar, N. A. \& Kaloeti, D. V. S. (2019). Hubungan antar regulasi diri dengan Fear of Missing Out (FoMO) pada mahasiswa tahun pertama Fakultas Psikologi Universitas Diponegoro, Jurnal EMPATI, 8(1), 136-143. Retrieved from https://ejournal3.undip.ac.id/index.php/empati/article/view/23587

Wanjohi, R. N., Mwebi, R. B., \& Nyang'ara, N. M. (2015). Self-regulation of Facebook usage and academic performance of students in Kenyan universities. Journal of Education and Practice, 6(14), 109-113. http://search.proquest.com/docview/1773217041?accountid=14744 